\title{
Active Leptin Fragments Resistant to Proteolytic Enzymes Present in Human Plasma
}

\author{
Paula Y. Tokuyama ${ }^{1}$, Edgar J. Paredes-Gamero², and Antonio Miranda ${ }^{1}$ \\ ${ }^{1}$ Department of Biophysics; ${ }^{2}$ Department of Biochemistry, Federal University of São Paulo, \\ São Paulo, SP, 04044-020, Brazil
}

\section{Introduction}

Leptin is a hormone produced and secreted predominantly from white adipose tissue and plays an important role in the regulation of energy homeostasis, food intake, body temperature and body weight maintenance. The tertiary structure of the leptin molecule shows the existence of a bundle of four helices that are characteristic of cytokines [1,2]. The main goal of this work is to study the structureactivity relationship of fragments of leptin. Peptides were designed taking into account preliminary studies involving the fragment Ac-hLEP ${ }_{89-98}-\mathrm{NH}_{2}$ (Ac-VLAFSKSSHL-NH2) developed by our group [3-5]. Peptides (Table 1) were synthesized by the solid-phase methodology, purified by HPLC and characterized by LC/ESI-MS and Amino Acid Analysis [6]. Resistance to proteolytic degradation assays were performed in human plasma in the absence and in the presence of enzymes class inhibitors (PMSF, E64, ortho-phenanthroline and pepstatin). The immunomodulatory capacity of the fragments against hematopoietic stem cells and mature populations were also evaluated. The progenitor cell count was made after treatment of bone marrow cells with $10^{-7} \mathrm{M}$ peptides in methylcellulose for 7 days $[7,8]$.

\section{Results and Discussion}

Resistance to proteolytic degradation assays were performed in plasma in the absence and in the presence of enzymes class inhibitors (PMSF, E64, ortho-phenanthroline and pepstatin). Degradation kinetics profiles were followed by LC/ESI-MS (Figure 1A). LEP1 and LEP5 showed to be very stable even after 6 hours of incubation. On the other hand, LEP2; LEP3; LEP4 and LEP6 (mouse sequence) were very instable and were degraded in just a few minutes of incubation. Only solutions of the peptides incubated in the presence of ortho-phenanthroline preserved the stability of the peptides, showing that metalloproteases should be responsible by the degradation of the leptin fragments. Figure 1B shows the results obtained with LEP3 and LEP4 that were taken as examples.
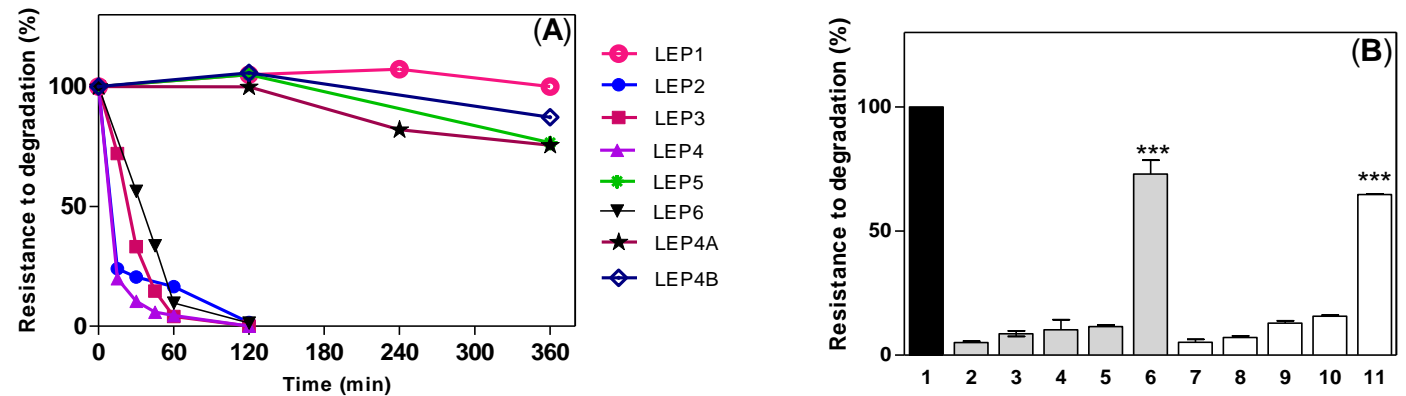

Fig. 1. Degradation profile in the absence $(A)$ and in the presence $(B)$ of proteolytic inhibitors of leptin fragments in plasma. Negative control; (2) LEP4; (3) LEP4+E64; (4) LEP4+Pepstatin; (5) LEP4+PMSF; (6) LEP4+Ortho-phenanthroline; (7) LEP3; (8) LEP3+E64; (9) LEP3+Pepstatin; (10) LEP3+PMSF; and (11) LEP3+Ortho-phenanthroline.

Due to its better performance in the biological activities evaluations, LEP4 was chosen to undergo chemical modification in order to increase its resistance to degradation, resulting in the compounds: LEP4A and LEP4B. Structure modification of LEP4A, was based on our knowledge of the cleavage site found by LC/ESI-MS. On LEP4A both serine residues were replaced by their corresponding D-counterpart. In contrast, LEP4B is the retro-inverso counterpart of LEP4. Both LEP4A and LEP4B 
Table 1. Leptin fragments.

\begin{tabular}{|c|c|c|}
\hline Abrev. & Name & Sequence ${ }^{a}$ \\
\hline LEP1 & {$\left[\mathrm{D}-\mathrm{Leu}^{4}\right]-\mathrm{OB} 3^{\mathrm{b}}$} & $\mathrm{S}-\mathrm{C}-\mathrm{S}-\mathrm{I}-\mathrm{P}-\mathrm{Q}-\mathrm{T}-\mathrm{NH}_{2}$ \\
\hline LEP2 & Ac-hLEP $113-122-\mathrm{NH}_{2}$ & $\mathrm{AC}-\mathrm{F}-\mathrm{S}-\mathrm{K}-\mathrm{S}-\mathrm{C}-\mathrm{H}-\mathrm{L}-\mathrm{P}-\mathrm{W}-\mathrm{A}-\mathrm{NH}_{2}$ \\
\hline LEP3 & Ac- $\left[\mathrm{Ser}^{96}\right]-\mathrm{hLEP}_{89-98}-\mathrm{NH}_{2}$ & $\mathrm{~A}_{C}-\mathrm{V}-\mathrm{L}-\mathrm{A}-\mathrm{F}-\mathrm{S}-\mathrm{K}-\mathrm{S}-\mathrm{S}-\mathrm{H}-\mathrm{L}-\mathrm{NH}_{2}$ \\
\hline LEP4 & Ac-[D-Phe ${ }^{92}$, Ser $\left.^{96}\right]-$ hLEP $_{89-98}-\mathrm{NH}_{2}$ & $\mathrm{Ac}-\mathrm{V}-\mathrm{L}-\mathrm{A}-\mathrm{f}-\mathrm{S}-\mathrm{K}-\mathrm{S}-\mathrm{S}-\mathrm{H}-\mathrm{L}-\mathrm{NH}_{2}$ \\
\hline LEP4A & Ac-[D-Phe $\left.{ }^{92}, \mathrm{D}-\mathrm{Lys}^{94}, \mathrm{D}-\mathrm{Ser}^{95,96}\right]-\mathrm{hLEP}_{89-98}-\mathrm{NH}_{2}$ & $A C-V-L-A-f-S-k-s-s-H-L-N_{2}$ \\
\hline LEP4B & Ri-Ac-[D-Phe ${ }^{92}$, Ser $\left.^{96}\right]-h_{L E P} 89-98-\mathrm{NH}_{2}$ & $\mathrm{~A} c-l-\mathrm{h}-\mathrm{s}-\mathrm{s}-\mathrm{k}-\mathrm{s}-\mathrm{F}-\mathrm{a}-\mathrm{l}-\mathrm{v}-\mathrm{NH}_{2}$ \\
\hline LEP5 & {$\left[\mathrm{Ser}^{2}, \mathrm{D}-\mathrm{Leu}^{4}\right]-\mathrm{OB} 3$} & $\mathrm{~S}-\mathrm{S}-\mathrm{S}-1-\mathrm{P}-\mathrm{Q}-\mathrm{T}-\mathrm{NH}_{2}$ \\
\hline LEP6 & Ac-[D-Phe ${ }^{92}$, Ser $\left.^{96}\right]-$ mLEP$_{89-98}-\mathrm{NH}_{2}$ & $\mathrm{AC}-\mathrm{L}-\mathrm{L}-\mathrm{A}-\mathrm{f}-\mathrm{S}-\mathrm{K}-\mathrm{S}-\mathrm{S}-\mathrm{S}-\mathrm{L}-\mathrm{NH}_{2}$ \\
\hline
\end{tabular}

${ }^{a}$ Small letters correspond to D-amino acid; ${ }^{b}$ Leinung and Grasso [9].

showed to be very stable to proteolytic action for more than 12 hours. The clonogenic capacity was evaluated and only LEP 2 could increase the CFU-GM. Conformational studies by circular dichroism technique did not indicate a clear correlation between biological activities, since all compounds presented a random conformation spectra profile.

\section{Acknowledgments}

This work was supported by grants and fellowships from CNPq and FAPESP.

\section{References}

1. Zhang, F.M., et al. Nature 387, 206-209 (1997), http://dx.doi.org/10.1038/387206a0

2. Kline, A.D., et al. FEBS Letters 407, 239-242 (1997), http://dx.doi.org/10.1016/S0014-5793(97)00353-0

3. Oliveira, V.X., et al. Regulatory Peptides 127, 123-132 (2005),

http://dx.doi.org/10.1016/j.regpep.2004.11.001

4. Oliveira, V.X., et al. J. Pept. Sci. 14, 617-625 (2008), http://dx.doi.org/10.1002/psc.957

5. Martins, M., et al. Regulatory Peptides 153, 77-82 (2009), http://dx.doi.org/10.1016/j.regpep.2008.11.013

6. Miranda, A., et al. J. Med. Chem. 40, 3651-3658 (1997), http://dx.doi.org/10.1021/Jm970311t

7. Dias, C.C., et al. Peptides 50, 24-27 (2013), http://dx.doi.org/10.1016/i.peptides.2013.09.012

8. Dias, C.C., et al. J. Cell. Biochem. 116, 1334-1340 (2015), http://dx.doi.org/10.1002/jcb.25090

9. Leinung, M.C.P. Grasso Regulatory Peptides 179, 33-38 (2012),

http://dx.doi.org/10.1016/j.regpep.2012.08.006 